\title{
English Teaching and Linguistics Journal (ETLiJ)
}

Vol. 1. No.2, 2020, pp. 44 - 48

E-ISSN: 2716-083

\section{Textual Function in English Morphology Online Classroom}

\author{
Tri Indah Rezeki ${ }^{1}$ \\ ${ }^{1}$ English Education Study Program, STKIP Budidaya Binjai \\ trindah.rizky@gmail.com
}

\begin{tabular}{|c|c|}
\hline ARTICLE INFO & ABSTRACT \\
\hline $\begin{array}{l}\text { Received } \\
14 / 05 / 2020 \\
\text { Revised } \\
03 / 07 / 2020 \\
\text { Accepted } \\
17 / 07 / 2020\end{array}$ & $\begin{array}{l}\text { A clause is a unit of message. As a message a clause divide into two } \\
\text { parts, namely the Theme and Rheme. The aim of this present research } \\
\text { is to analyze textual function in English Morphology online } \\
\text { classroom. The scopes of this research are analysis of textual } \\
\text { function in English Morphology online classroom, classification of } \\
\text { Theme in English Morphology online classroom and kinds of Theme }\end{array}$ \\
\hline $\begin{array}{l}\text { Keywords: } \\
\text { Textual Function, } \\
\text { Theme and Rheme, } \\
\text { Unmarked and } \\
\text { Marked Theme, } \\
\text { Simple and Multiple } \\
\text { Theme }\end{array}$ & $\begin{array}{l}\text { dominantly used in English online classroom. The researcher applied } \\
\text { descriptive qualitative research to collect the data from the discourse } \\
\text { of the lecturer and the students in English Morphology online } \\
\text { classroom at Universitas Islam Negeri Sumatera Utara. The data } \\
\text { was obtained into three phases namely separated the text into } \\
\text { clauses, analyzed each clause in terms of the textual function (i. e } \\
\text { Theme and Rheme) and classified elements of the Themes (into the } \\
\text { four types of Theme). The data indicated that the lecturer and the } \\
\text { students used textual function in their discourse in online classroom. } \\
\text { Kinds of textual function they used were } 7 \text { Unmarked Simple Theme } \\
\text { (UST), } 3 \text { Unmarked Multiple Theme (UMT), 16 Marked Simple } \\
\text { Theme (MST), and } 2 \text { Marked Multiple Theme (MMT). In this case, } \\
\text { MST was dominant used by the leacturer and the students in English } \\
\text { online classroom. }\end{array}$ \\
\hline
\end{tabular}

How to cite: Rezeki, T. I. (2020). Textual Function in English Morphology Online Classroom. English Teaching and Linguistics Journal, 1(2), 44-48.

\section{INTRODUCTION}

Discourse is one of the four systems of language, the others being vocabulary, grammar and phonology. Discourse has various definitions but one way of thinking about it is as any piece of extended language, written or spoken, that has unity and meaning and purpose. To understand the communication, we must be able to master the language and its elements such as vocabulary, structure, and so forth, Rezeki and Sagala (2019).

The function of language to arrange or weave the message in a clause is termed as textual function, Halliday (2004) and Saragih (2011). The textual function indicates how a chunk of message is arranged or interwoven in such a way that the chunk, piece or part of message is chained with another or the other parts so that the bits of message become united or forms a unity or oneness. This is another way of saying that textual function creates relevance of one chunk of the message to another so that a relatedness and unity forms. The relatedness and unity is called the texture. One of the fundamental characteristics of a text is that its texture.

Because of the varieties of people's discourse especially in weaving the message, the reasearcher was interested to conduct this research. In this case, the varieties of the discourse 
found in English Morphology online classroom. The scopes of this research are analysis of textual function in English Morphology online classroom, classification of Theme in English Morphology online classroom, and kind of Theme dominantly used in English online classroom. Based on the background of the study, the aims of this study are to analyze kinds of textual function in English Morphology online classroom, to classify The Theme used in English Morphology online classroom and to investigate kinds of the Theme dominantly used in English Morphology online classroom.

In English (and other languages such as bahasa Indonesia) the Theme is determined by order that is to say that the Theme in English occupies the initial functional position of the clause. This operationally clarifies that the Participant, Circumstance or Process may function as a Theme in English. The rest of the clause after the Theme is called the Rheme. Table 1. 1 shows the Theme and Rheme in English clauses.

Table 1

Theme and Rheme

\begin{tabular}{ll}
\hline THEME & RHEME \\
\hline Your reporter & repeatedly interrupted her replies. \\
Repeatedly & your reporter interrupted her replies. \\
Her replies & were repeatedly interrupted by your reporter. \\
Your health & we care \\
We & care (for) your health \\
Open & the door please \\
Write & the letter now \\
\hline
\end{tabular}

Halliday (2004) distinguises the Theme into unmarked and marked. An unmarked Theme is one which carries a common or usual way of conveying message in a clause. In contrast, a marked Theme conveys message in a clause not in a common way. In English the markedness of Theme is related to the interpersonal function. It can be said that an unmarked Theme is determined with reference to the Mood. The Theme is unmarked if the Theme and the Subject are conflated. In other words, when the Theme of the clause also functions as the Subject in a declarative mood, the Theme is unmarked. In an imperative Mood clause, the Theme is conflated with the Process. Further, in an interrogative clause, the Theme is conflated with the finite.

Halliday (2004) also explains the Theme of a clause may be simple or multiple. A simple Theme occupies only one functional position in a clause. The functional position may be the Participant, Circumstance or Process. A simple Theme may be constituted or filled by one or more than one word, phrase or clause. Examples of clauses with the four kinds of Theme are displayed in Table 1.2.

Table 2

Theme Generated by its Markedness and Complexity

\begin{tabular}{lll}
\hline THEME & RHEME & REMARKS \\
\hline My uncle & bought a new car for my mother yesterday & UST \\
Yesterday & my uncle bought a new car for my mother. & MST \\
So my uncle & bought a new car for my mother yesterday. & UMT \\
So yesterday & my uncle bought a new car for my mother. & MMT \\
John, pass & me the salt. & UMT \\
Pass & the salt here, John & UST \\
Well, well did you & see my uncle at the party? & UMT \\
Your health & we care & MST
\end{tabular}




\begin{tabular}{lll} 
We & care (for) your health. & UST \\
They & did not pay the bill & UST \\
\hline Note. $\mathrm{U}=$ Unmarked; $\mathrm{M}$ = Marked; $\mathrm{S}=$ Simple; $\mathrm{M}=$ Multiple; $\mathrm{T}=$ Theme. &
\end{tabular}

Textual function is one of interesting topic to be researched by other researchers. First, Amalia (2016) did a research about Textual Function Variations of Foreign Embassies' Press Releases and Their Implications for Translaton Teaching. The result shows that the global overall textual function variation of the translational texts is very low which is represented by the mean of 1.25. In other words, the difference between Text 1 in Bahasa Indonesia (T1) and Text 2 in English (T2) is not significant. Second, Briones (2016) conducted a research about Textual Analysis through Systemic Functional Linguistics. His research identified the similarities and differences between two texts, a movie review and a news article that dealt with the same topic, namely, the movie "Star Wars: The Force Awakens". Third, Kazemi (2016) analyzed a work about Textual Metafunction in Persian Economic and Sports Texts. Data analysis of the project presented that all kinds of themes (simple, multiple, marked and unmarked) are used in sports and Economic press texts. However, they both share similarities and diversities. The difference in the mentioned texts is that the economic ones contain more multiple themes. But in sports texts simple themes are applied.

This study is expected can give contribution theoretically and practically. Theoretically, the result can give knowledge, experience, perception and material in research methodology application especially the description of analysis focuses on textual function. Practically, this study is conducted to know analysis of textual function in online classroom so that it can be a reference for English teaching-learning especially in Discourse Analysis.

\section{METHODS}

The method of this research is descriptive qualitative as Trochim and William (2006) stated that the descriptive qualitative research is used to investigate the social phenomenon. Moreover, Bogdan and Biklen (1992) also quote that descriptive qualitative is one of the research procedures which produce of descriptive data in form of speech and the behavior of those being observed.

The data of this research was the discourse of the lecturer and the students in English Morphology online classroom at Universitas Islam Negeri Sumatera Utara and it was analyzed based on the textual function by Halliday (2004). The data was obtained into three phases namely separated the text into clauses, analyzed each clause in terms of the textual function (i. e Theme and Rheme) and classified elements of the Themes (into the four types of Theme). In collected the data, researchers used instruments namely literature review, documentation and note technique by Sugiyono (2011) and to check the data validation, the triangulation was used in this research by combining the information from both the discourse of the lecturers and the students in English Morphology online classroom and the techniques of data collection.

\section{RESULT AND DISCUSSION}

\subsection{Result of the Study}

\subsubsection{Analysis of Theme and Rheme}

The analysis of clause is presented in Table 3.1. The table shows what elements constitute the Theme and at the same time specifies the markedness and complexity of the Theme.

Table 3

Analysis of Theme and Rheme

\begin{tabular}{ll}
\hline THEME & RHEME \\
\hline 1. We & are from group 6 \\
2. Today & we will discuss about the process of words \\
& formation \\
3. Please & watch our video carefully and seriously \\
4. The first explanation & From me, Chairunnisa \\
5. The next explanation & Will be continued by Rizky viola
\end{tabular}



6. The next explanation
7. Now
8. So this is
9. We
10. I
11. Please
12. Can
13. In page 3 about derivation
14. So I
15. I
16. And my question
17. My question

18. How

19. Please

20. Thank you

21. I

22. That

23. Do

24. Is

25. I

26. Thank you

27. And thank you

28. Your names
By Zahra

We will open question and answer section your time

Choose 6 person only

Wanna ask you

Explain specifically according to your Group

You please give me the example of word

formation in a compounding form?

There are example kinds of word formation process

Wanna ask you about the example of

adejctives to noun

Want to ask group six

Is what the difference between inflection and derivation is?

Is compound nouns should not be confused with nouns modified by adjective, verb and other nouns

Are the compound noun form?

Give us time to answer the question

For your question

Will answer Zein's question

Is my answer

You understand?

It clear the answer we have given?

Think all questions have been answered well

For your participation today

For sending assignment on time

Can be seen in elearning.uinsu.ac.id

\subsubsection{Classification Theme}

After analyzing the discourse and separating into clauses, it is found that the discourse employs the four types of Theme. In other words, the classification of Theme results in four types of Theme: UST, UMT, MST and MMT. The proportion of each type of Theme is summarized in Table 3.2 as the following.

Table 4

Themes and the Proportion in the Discourse

\begin{tabular}{lllcc}
\hline No. & \multicolumn{2}{l}{ TYPES OF THEME } & NUMBER & PERCENTAGES \\
\hline 1 & Unmarked Simple Theme & (UST) & 7 & 25 \\
2 & Unmarked Multiple Theme & (UMT) & 3 & 11 \\
3 & Marked Simple Theme & (MST) & 16 & 57 \\
4 & Marked Multiple Theme & (MMT) & 2 & 7 \\
\hline
\end{tabular}

It is found that out of the four kinds of textual function i.e Unmarked Simple Theme (UST), Unmarked Multiple Theme (UMT), Marked Simple Theme (MST) and Marked Multiple Theme (MMT) were used by the lecturers and the students in English Morphology online classroom. The Marked Simple Theme is dominantly used with the proportion of 57\%. In other words, more than one half of the processes in the discourse belong to Marked Simple Theme (MST).

\subsection{Discussion}

The overall discussion of this study is to analyze textual function used by the lecturer and the students in English Morphology online classroom. As Halliday (2004) and Saragih (2011) state that the function of language to arrange or weave the message in a clause is termed as textual function. The textual function indicates how a chunk of message is arranged or 
interwoven in such a way that the chunk, piece or part of message is chained with another or the other parts so that the bits of message become united or forms a unity or oneness. The researcher is interested to conduct this study because of the varieties of people's discourse especially in weaving the message. In this case, the varities of the discourse found in English Morphology online classroom.

By applying Halliday's and Saragih's theories about textual function, the finding indicates that the lecturers and the students used textual function in their discourse during teachinglearning process. The four kinds of textual function found in their discourse namely Unmarked Simple Theme (UST), Unmarked Multiple Theme (UMT), Marked Simple Theme (MST) and Marked Multiple Theme (MMT). In this case, Markd Simple Theme (MST) is dominant used by the lecturers and the students in English Morphology online classroom.

\section{CONCLUSION}

Based on the result finding, it can be concluded that the lecturers and the students of English Morphology class at Universitas Islam Negeri Sumatera Utara realized textual function in their discourse during the process of teaching-learning in online classroom. It means that the online classroom has varieties of discourse in terms of textual function which is limited on Theme and Rheme.

\section{REFERENCES}

Amalia. (2016). Textual Function Variations of Foreign Embassies' Press Releases and Their Implications for Translaton Teaching. Lingtera

Bogdan and Biklen. (1992). Qualitative Research for Education: An Introduction to Theory and Method. Boston: Allyn and Bacon Inc.

Briones. (2016). Textual Analysis through Systemic Functional Linguistics. Journal of English Language Teaching and Linguistics

Halliday, M., Matthiessen, C. M., \& Matthiessen, C. (2014). An introduction to functional grammar. Routledge.

Kazemi. 2016. Textual Metafunction in Persian Economic and Sports Texts. International Journal on Studies in English Language and Literature

Rezeki, T. I., \& Sagala, R. W. (2019). A MORPHOLOGICAL ANALYSIS OF DERIVATIONAL AND INFLECTIONAL MORPHEMES. Serunai: Jurnal Ilmiah Ilmu Pendidikan, 5(2), 159-162.

Saragih, A. (2011). Introducing English Systemic Functional Grammar of English. Unimed, Medan (unpublished).

Sugiyono. (2011). Metode Penelitian Pendidikan Kuantitatif, Kualitatif, dan R \& D. Bandung: Alfabeta

Trochim and William M.K. (2006). Descriptive Statistics. Research Methods Knowledge Base. Retrieved March 14th2011 